\title{
СУЧАСНІ АСПЕКТИ ОЦІНКИ ЯКОСТІ ЖИТТЯ У ХВОРИХ НА ХРОНІЧНЕ ОБСТРУКТИВНЕ ЗАХВОРЮВАННЯ ЛЕГЕНЬ
}

\author{
У. А. Ленець, О. М. Стельмах \\ ДВНЗ «Тернопільський державний медичний університет \\ імені І. Я. Горбачевського МОЗ України»
}

У статті проаналізовано сучасні методи оцінки якості життя у хворих на хронічне обструктивне захворювання легень та роль медичної сестри у проведенні опитувань пацієнтів даної групи.

\section{MODERN ASPECTS OF QUALITY OF LIFE IN PATIENTS WITH CHRONIC OBSTRUCTIVE PULMONARY DISEASE}

\author{
U. A. Lenets, O. M. Stelmah \\ SHEI «Ternopil State Medical University by I. Ya. Horbachevsky of MPH of Ukraine»
}

The article analyzes the modern methods for evaluating the quality of life in patients with chronic obstructive pulmonary disease and the role of the nurse in conducting polls of this group of patients.

Вступ. На сьогодні у світі зберігається висока захворюваність та смертність від хронічних обструктивних захворювань легень (ХОЗЛ), які протягом багатьох років $\epsilon$ однією 3 провідних причин смертності населення у багатьох економічно розвинених кра нах світу і значною медичною та соціальною проблемою $[1,8,11]$. Хронічний характер патологі, обмеження функціональних можливостей, необхідність тривало, а в деяких ситуаціях, і постійно терапі, незмінно призводить до модифікаці способу життя пацієнта, що, в свою чергу, ініціює появу проблем соціально адаптаці та погіршення якості життя (ЯЖ) $[4,10]$.

У сучасній медицині ЯЖ розглядається як інтегральна характеристика стану хворо людини, що складається з фізичного, психологічного, соціального компонентів. Кожен із компонентів, у свою чергу, включає цілий ряд складових, наприклад, фізичний - симптоми захворювання, можливість виконання фізично роботи, здатність до самообслуговування; психологічний - тривогу, депресію, ворожу поведінку; соціальний - соціальну підтримку, роботу, громадські зв'язки тощо [6].

х всебічне вивчення дозволяє визначити рівень якості життя як окремо особи, так і цілих

() У. А. Ленець, О. М. Стельмах, 2015 груп, зокрема хворих на ХОЗЛ, і встановити, за рахунок якого складника він підвищується чи знижується та на що необхідно вплинути, щоб покращити якість життя (скоригувати лікування, надати соціальну підтримку та ін.).

Основна частина. ХОЗЛ належить до системних захворювань, які невпинно прогресують, i, за результатами дослідження The Global Burden of Disease (GBD) stady, займає 6-те місце у структурі смертності населення, а за прогнозами, у 2030 р. посідатиме 4-те місце [5].

За даними Інституту фтизіатрі і пульмонологі імені Ф. Г. Яновського АМН Укра ни, на ХОЗЛ страждає близько $7 \%$ населення Укра ни, що приблизно складає 3 млн осіб [2]. Це захворювання переважно охоплює працездатне населення середнього віку, часто $є$ причиною інвалідності і вимагає тривалого, а в більшості випадків, довічного лікування, що призводить до значних економічних втрат та формування соціальних проблем [3].

В останні десятиліття відзначено безперечні успіхи в лікуванні пацієнтів з ХОЗЛ, що пов'язано зі швидкими темпами розвитку клінічно фармакологі та розробкою нових високоефективних схем терапі дано категорі хворих. Проте хронічний перебіг патологі, порушення функціональних можливостей та тривала терапія призводять до змін способу життя пацієнта, вини- 
кає соціальна дизадаптація та погіршення ЯЖ $[4,10]$.

Відповідно до рекомендацій Всесвітньо організаці охорони здоров'я, ЯЖ визначається як індивідуальне співвідношення людиною свого становища в житті суспільства $з$ власними цілями, планами, можливостями і ступенем загально невлаштованості. На оцінку ЯЖ впливає цілий ряд факторів: фізичний, психічний і емоційний стан людини, а також ступінь його незалежності, громадське положення, особисті уявлення і стан навколишнього середовища [11]. Однак не варто забувати про такий важливий показник ЯЖ, як здатність хворо людини адаптуватися до проявів свого захворювання і відчувати себе комфортно в цій ситуаці . Тому тоді, як для лікаря одним із головних завдань при веденні хворого $є$ досягнення клініко-лабораторно ремісі та запобігання прогресуванню захворювання, то для пацієнта першочерговою метою $€$ поліпшення самопочуття і всіх аспектів ЯЖ [6].

Саме тут необхідно виокремити роль медично сестри як важливо об'єднувально ланки між лікарем і пацієнтом, діяльність яко може наблизити об'єктивні клінічні дані з суб'єктивними переживаннями пацієнта. Адже однією із запорук вчасно діагностики та адекватно терапі $\epsilon$ освіченість та розуміння пацієнта щодо власного захворювання: перших суб'єктивних та клінічних проявів, $x$ розвиток, а також - ймовірність та небезпека виникнення ускладнень. В тісній співпраці та під наглядом лікаря медсестра може здійснювати низку заходів, скерованих на навчання пацієнтів. Можна використовувати вже добре відомі навчально-роз'яснювальні методики: ознайомлення з правилами та інструкціями, пізнавальні бесіди, тематичні лекці тощо. Особливо актуальним та вагомим щодо практично цінності $€$ проведення анкетування пацієнтів. Варто зауважити, що на даний момент $\epsilon$ анкети як загального, так і вузького спрямування, що стосуються певно нозологі.

Якість життя пацієнтів з ХОЗЛ потрібно оцінювати за допомогою таких опитувальників [7, 9, 10]:

- стандартизований неспецифічний опитувальник SF-36 (Medical Outcomes Study 36-Item Short-Form Health Status) - 36 питань, що дозволяють найбільшою мірою оцінювати взаємозв'язок ЯЖ з соціальним статусом, психічним здоров'ям і загальним благополуччям індивідуума;

- респіраторний опитувальник госпіталю Святого Георгія (SGRQ) - 76 питань, структурованих таким чином, що відповіді на них відображають суб'єктивну оцінку пацієнтом респіра- торних порушень, фізично активності та обмежень, психосоціально адаптаці, вплив статусу здоров'я на трудову і повсякденну діяльність, емоційного сприйняття хвороби, відносин з близькими людьми, потреби в лікуванні та прогнозу захворювання;

- Тест оцінки ХОЗЛ (TOX) (COPD Assessement Test (CAT)).

Щодо опитувальника SF-36, то варто зауважити, що він складається з 36 питань, об'єднаних у 8 наступних шкал: фізична активність ФА (оцінює міру самообслуговування, ходьбу, піднімання по сходах, перенесення важких речей, а також виконання значних фізичних навантажень); роль фізичних проблем в обмеженні життєдіяльності РФ (характеризує ступінь обмеження у повсякденній діяльності через проблеми 3 фізичним здоров'ям), інтенсивність болю ІБ (відображає інтенсивність больового синдрому та його вплив на здатність займатися нормальною діяльністю); загальний стан здоров'я (оцінка 3С3); життєва активність - ЖА (оцінка відчуття пацієнтом повноти сил та енергі ); соціальна активність - СА (задоволення від спілкування, проведення часу з друзями, родиною, сусідами, колегами); роль емоційних проблем в обмеженні життєдіяльності - PE (оцінка ступеня, де емоційний стан заважає виконанню роботи або іншо звичайно повсякденно діяльності, включно великі витрати часу на $\mathrm{x}$ виконання, зменшення обсягу зроблено роботи, зниження якості); психічне здоров'я - ПЗ (характеризує настрій, наявність депресі, тривоги, оцінює загальний показник позитивних емоцій).

Фізичний статус пацієнта оцінюється за п'ятьма шкалами (ФА, РФ, ІБ, ЗСЗ, ЖА), психосоціальний статус також характеризують п'ять шкал (PE, CA, П3, 3С3, ЖА). Причому показники ЗС3 та ЖА визначаються як фізичним, так і психічним статусом людини.

Максимальне значення для всіх шкал, при повній відсутності обмежень чи порушень здоров'я, дорівнювало 100. Чим вищим був показник по кожній шкалі, тим кращою була ЯЖ по цьому параметру.

При аналізі ЯЖ за респіраторним опитувальником госпіталю Святого Георгія (SGRQ) в якості оціночних параметрів застосовуються 4 узагальнених шкали: «симптоми» - суб'єктивна оцінка пацієнтом ступеня виразності клінічних ознак ХОЗЛ; «активність» - суб'єктивна оцінка пацієнтом ступеня обмеження фізично активності, зумовлено захворюванням; «вплив» - суб'єктивна оцінка пацієнтом виразності психологічних і соціальних проблем у результаті захво- 
рювання і «сума» - загальний показник ЯЖ, що характеризує в цілому негативний вплив ХОЗЛ на стан здоров'я.

Оцінка кожно шкали проводиться за 100бальною системою. Оціночні критері $\epsilon$ зворотними: чим вищий бал, тим більш негативним $є$ вплив хвороби на ЯЖ пацієнта. Даний опитувальник дозволяє розраховувати ЯЖ хворих як у цілому, так і окремо за кожною із трьох шкал.

Стосовно останнього опитувальника TOX, слід зауважити, що він особливо активно використовується в практичній роботі для оцінки тяжкості та ушкоджуючого впливу ХОЗЛ, відповідно до міжнародного узгоджувального документу GOLD. Він вміщує 8 пунктів, які виміряють погіршення статусу здоров'я при ХОЗЛ. Загальний

\section{ЛІТЕРАТУРА}

1. Железнякова Н. М. Оцінка якості життя у пацієнтів із поєднаним перебігом хронічного обструктивного захворювання легень і хронічного панкреатиту / Н. М. Железнякова / / Вісник ХНУ імені В. Н. Каразіна. - 2012. - № 998. - С. 29-33.

2. Фещенко Ю. И. Актуальные вопросы хронического обструктивного заболевания легких / Ю. И. Фещенко / / Український пульмонологічний журнал. 2010. - № 1. - C. 6-11.

3. Хронічне обструктивне захворювання легень: етіологія, патогенез, класифікація, діагностика, терапія (проект національної угоди) / Ю. І. Фещенко, Л. О. Яшина, О. Я. Дзюблик [та ін.] / / Український пульмонологічний журнал. - 2013. - № 3. - С. 6-12.

4. Качество жизни у пациентов с хронической обструктивной болезнью легких: можем ли мы ожидать большего? (результаты национального исследования ИКАРХОБЛ) / А. Г. Чучалин, А. С. Белевский, С. И. Овчаренко, И. А. Королева / / Пульмонология. - 2006. - № 5. - C. 19-27.

5. Шкарівський Ю. Л. Показники якості життя пацієнтів із хронічним обструктивним захворюванням легень у поєднанні із гастроезофрагальною рефлексною хворобою / Ю. Л. Шкарівський, М. А. Станіславчук // Український терапевтичний журнал. - 2014. - № 3-4. C. 56-62. рахунок знаходиться в межах від 0 до 40; тісно корелює із статусом здоров'я, що виміряється згідно 3 опитувальником госпіталю Святого Георгія, надійним та чутливим. Загальний рахунок TOX визначається як сума балів відповідей на кожне з восьми запитань.

Висновок. Застосування сучасних методик оцінки якості життя у хворих на ХОЗЛ дає можливість оцінити рівень благополуччя і задоволення тими сторонами життя, на які впливає хвороба чи лікування. Проведення опитування $є$ важливою складовою в структурі діяльності медично медсестри з пацієнтами хворими на ХОЗЛ. Застосування сучасних опитувальників $\epsilon$ вагомим практичним та об'єктивним елементом діагностичного пошуку, а також кроком до усвідомлення власно патологі пацієнтом.

6. Ягенський А. В. Оцінка якості життя у сучасній медичній практиці / А. В. Ягенський, І. М. Січкарук // Внутрішня медицина. - 2009. - № 5-6 (17-18). - С. 2428.

7. Ferrer M. Interpretation of quality of life scores from the St. George's Respiratory Questionnaire / M. Ferrer, C. Villasante, J. Alonso [et al.] / / Eur. Respir. J. - 2002. - № 19. - P. 405-413.

8. From the Global Strategy for the Diagnosis, Management and Prevention of COPD, Global Initiative for Chronic Obstructive Lung Disease (GOLD), 2010. Available from : http: / / www.goldcopd.org/.

9. Jones P.W. St George's Respiratory Questionnaire: MCID / P.W. Jones / / Journal of COPD. - 2005. - № 2. -P. 75-79.

10. Kardos P. Primary care physician assessment of COPD severity : European Health-related Quality of Life in COPD study / P. Kardos, P. W. Jones, M. L. Levy [et al.] // Eur.Resp. J. - 2010. - Vol. 36, Suppl. 54. - P. 4228.

11. World Health report. World Health Organization. Available from : http://www.who.int/respiratory/ copd/en/ 